\title{
PRICE BEHAVIOR ANALYSIS OF BRAZILIAN YERBA MATE EXPORTED TO URUGUAY BETWEEN 1997 AND 2018
}

\author{
Jaqueline de Paula Heimann ${ }^{1}$, Marco Antônio Dias Machado², João Carlos Garzel Leodoro da
} Silva $^{3}$, Thiago Rodrigues de Paula ${ }^{4}$, Vitor Afonso Hoeflich ${ }^{5}$, Francisco Costa Junior ${ }^{6}$

${ }^{1}$ Universidade Federal do Paraná, Pós Graduação em Engenharia Florestal, Curitiba, Paraná, Brasil jaquelineheimann@yahoo.com.br

${ }^{2}$ Universidade Federal do Paraná, Pós Graduação em Engenharia Florestal, Curitiba, Paraná, Brasil mak_adm@hotmail.com

${ }^{3}$ Universidade Federal do Paraná, Pós Graduação em Engenharia Florestal, Curitiba, Paraná, Brasil garzelufpr@gmail.com.br

${ }^{4}$ Universidade Federal do Paraná, Pós Graduação em Engenharia Florestal, Curitiba, Paraná, Brasil uf_floresta@hotmail.com

${ }^{5}$ Universidade Federal do Paraná, Pós Graduação em Engenharia Florestal, Curitiba, Paraná, Brasil - vitor.ufpr@gmail.com ${ }^{6}$ Universidade Federal do Paraná, Pós Graduação em Engenharia Florestal, Curitiba, Paraná, Brasil - jr-florestal@live.com

Received for publication: 06/03/2019 - Accepted for publication: 09/04/2021

\begin{abstract}
Resumo
Análise do comportamento do preço da erva-mate brasileira exportada para o Uruguai entre 1997 e $2018 . \mathrm{O}$ presente trabalho teve por objetivo avaliar a sazonalidade do preço da erva-mate brasileira destinada ao mercado uruguaio, servindo como base para a tomada de decisão por parte dos produtores. Para isso, coletou-se dados relativos às exportações brasileiras de erva-mate para o Uruguai, disponibilizados no Sistema ALICE-WEB, que, após o deflacionamento, foram utilizados para a determinação do Índice Sazonal para diferentes períodos entre os anos de 1997 e 2018. Os resultados mostraram que o mercado de erva-mate não apresenta ciclos históricos regulares, os preços do produto brasileiro no mercado uruguaio sofrem quedas e aumentos constantes. Ainda assim, é possível observar uma tendência, de longo prazo, de aumento no preço real do produto a uma taxa média de $0,33 \%$ ao mês. É possível concluir que o preço da erva-mate brasileira no mercado uruguaio estava em ascendência até o início do ano de 2015, quando a Justiça Uruguaia instaurou inquérito para averiguar a presença de cádmio e chumbo em níveis acima do permitido no produto brasileiro. Ao final do período estudado, houve leve tendência de recuperação dos preços, no entanto, apenas novos estudos serão capazes de comprovar se o preço da erva-mate brasileira no mercado uruguaio atingirá novamente patamares similares aos registrados antes do embargo judicial.
\end{abstract}

Palavras-chave: comércio internacional; sazonalidade; competitividade.

\begin{abstract}
The objective of this study was to evaluate price seasonality of the Brazilian Yerba mate exported to the Uruguayan market, serving as a basis for decision-making to the producers. For this purpose, we collected data on Brazilian yerba mate exports to Uruguay, available in the ALICE-WEB System, which, after deflation, were used to determine the Seasonal Index for different periods between 1997 and 2018 The results showed that the market for yerba mate does not present regular historical cycles, the prices of the Brazilian product in the Uruguayan market suffer constant falls and increases. Nevertheless, it is possible to observe a long-term trend of increasing the real price of the product at an average rate of $0.33 \%$ per month. It is possible to conclude that the price of Brazilian yerba mate in the Uruguayan market was in the ascendancy until the beginning of 2015, when the Uruguayan Justice instituted an investigation to investigate the presence of cadmium and lead at levels above the allowed ones in the Brazilian product. At the end of the study period, there was a slight tendency to recover prices, however, only new studies will be able to verify if the price of Brazilian yerba on the Uruguayan market will reach levels similar to those registered before the judicial embargo.
\end{abstract}

Keywords: international trade; seasonality; competitiveness.

\section{INTRODUCTION}

Yerba mate (Ilex paraguariensis A. St.-Hil.) is produced in Argentina, Brazil and Paraguay. Yerba mate at the beginning of the 20th century held the status of the main export product in the southern region of Brazil, even being disputed by companies from both states Santa Catarina and Paraná (DALLABRIDA 2012).

Although Argentina has the largest yerba mate production area in the world, Brazil has been gaining prominence in the productive and commercial scenario. Despite having a harvested area that is less than half of the harvested area in Argentina, Brazil presents higher productivity, being responsible for $65 \%$ of the world production of yerba mate (OLIVEIRA; WAQUIL, 2015) 
The main importer of Brazilian yerba mate is Uruguay (DUTRA et al., 2010). For this reason, the Uruguayan market was studied in this article isolated from any other external market. However, it is worth remembering that the price formation is defined in the international market with the participation of all importers.

Brazilian production is concentrated in the southern region, with emphasis on the state of Paraná. According to Chechi and Schultz (2016), the growth of production in this state occurs mainly due to the preservation of native trees and to the continuous exploration, as well as constant investment in the sector.

The growing recognition of the importance and contribution of non-timber forest products in socioeconomic and environmental aspects has aroused global interest in these products, since they play an important role in generating income, especially in rural areas (ELIAS; SANTOS, 2016; MAISHAROU; LARWANOU, 2015).

Therefore, knowledge about the seasonal behavior of the main competitive factors, such as price, is of uttermost importance for obtaining positive increase in competitive advantage, aiming not only at increasing production or reducing costs, but also at taking advantage of the behavioral information of the market variables, thus being able to guide organizations in sales strategies which promote competitive improvement (CARDOSO, et al. 2013).

According to Soares et al. (2015) seasonal behavior in agribusiness, globally and specifically, has been studied in works published since the 1960s. However, in the forest-based sector, research is still incipient, with emphasis on the work of Santana, Santos and Oliveira (2010), who studied the historical behavior of local and international timber production and trade in the state of Pará, Santana et al (2018) who researched the seasonal behavior, occurrence of cycles and the price trend of Brazil Nut exportations, and Oliveira and Waquil (2015) who evaluated the dynamics of commercialization, through prices of yerba mate in Rio Grande do Sul.

Noting the relevance of the theme and the absence of studies in this area, the present work aimed to analyze the export price seasonal pattern of Brazilian yerba mate to Uruguay, from 1997 to April 2018, to check whether or not there are possible cycles within this time interval and by comparing them, to serve as a basis for suggesting strategies and, consequently, increasing the sector competitiveness.

Yerba mate agribusiness has economic importance especially for the southern states of Brazil, for the generation of jobs and for being an alternative source of income for small and medium-sized agricultural properties (ROCHA JUNIOR et al., 2004). The consumer market for yerba mate has been increasing, since the product is no longer linked only to the production of tea, chimarrão or tereré, but also to its use in the food, cosmetic and health industry (WOLF; PEREIRA, 2016).

Considering the economic contribution of the product to the country, studies that may enable a better understanding of the product price formation process are of paramount importance and may assist in prospective analysis and decision-making by market agents, as well as by sectoral policy makers.

\section{MATERIAL AND METHODS}

Due to the importance of exports in the yerba mate chain, this study was developed for the product "yerba mate", registered under the code 090300.

Monthly data, export quantity and value, in US \$, were collected in the Alice-web system, in the period comprising January 1997 to April 2018, totaling 256 observations. The selection of the period took place according to the availability of data in the system.

Export values were deflated by the United States Consumer Price Index (CPI), considering April 2018 as the base period. After deflation, the unit price of Brazilian yerba mate in the Uruguayan market was obtained according to equation 1

$$
P u=\frac{R b}{Q(1)}
$$

Where: $\mathrm{Pu}$ - unit price of the product (US \$ / t); Rb - real gross revenue (US \$); Q - quantity exported (t).

\section{Deseasonalization of data}

The seasonality analysis is an important tool for yerba mate exporting companies, as it allows for detailed planning of the production and marketing of the product throughout the year due to this variation, seeking to increase profitability and competitive advantage.

To determine the seasonal variation in the prices of Brazilian yerba mate, marketed to Uruguay, the seasonal index was initially calculated for the period from January 1997 to April 2018, applied to the moving average of prices, according to equation 2, thus allowing to observe the variation in the price of yerba mate, throughout the period of analysis, based on its average value. 


$$
I E t=D i j=\frac{P t}{G t}
$$

Where: IEt and Dij - Seasonal index; Pt - Unit price (US \$ / t); Gt - Geometric Moving Average of prices.

From the seasonal index, the seasonal price index was determined, which shows the trend of oscillation of the variable, according to equation 3 (HOFFMANN, 2006).

$$
E_{-} j=\frac{G_{-} j}{C * 100}
$$

Where: $\varepsilon j$ - Seasonal Index; $\mathrm{Gj}$ - Geometric Average of the prices of the $\mathrm{j}$-th month; C - Geometric Average of the seasonal indexes

In addition, the Irregularity Index was calculated, which makes it possible to determine the lower and upper limits of the seasonal indexes, by means of the product and the ratio between the seasonal and irregularity indices, respectively (HOFFMANN, 2006).

The ratio between the price and the seasonal index makes it possible to obtain the seasonally adjusted values of the historical price series, with equation 5:

$$
P t(d)=\frac{P t}{\in j * 100}
$$

Where: Pt (d) - Seasonally adjusted price; Pt - Unit price (US \$ / t); j - Seasonal index.

\section{Cycle analysis}

In time series, cycles can be considered as movements of a variable rising and falling, around an average level or trend, without necessarily presenting periodic behavior. That is, they are characterized by long waves, with a certain regularity, around a trend line.

The analysis and study of structural break is associated with econometrics that uses data in time series, and by structural break it is understood that there are one or more changes in the series level, in the dispersion and / or slope. Changes that may arise on a specific date or gradually evolve over a period.

According to Hansen (2001), the practical and applied study of time series is based on the premise that it is stationary, with its parameters, such as mean and variance, being stable over the analyzed period. Therefore, if there is a break in the series, this premise is violated and the parameters, if they do not incorporate this information, may be biased.

For this stage of the research, the unit prices of the product were plotted in a graph, seeking a visual analysis of its variation, in which the objective was to identify the occurrence of series break and the division of the period evaluated in cycles.

These breaks follow the cyclical behavior described by Castro and Sousa Neto (2013), with repeated oscillations over four phases, namely: prosperity (peak), recession (contraction), depression (bottom) and growth (expansion). They come from combinations of factors that affect the economy.

To confirm the time series breaks, the Chow test was used, which tests the null hypothesis that the coefficients of the equation are the same between two periods, against the alternative that the coefficients are different in the two sub periods (CHOW, 1960 ). In this way, it is possible to evidence whether there has been a change in the price behavior of Brazilian yerba mate exported to Uruguay. From this, the monthly geometric rate was calculated for the break periods of the series pointed out as significant by the Chow test. The data were tabulated in an Excel spreadsheet and in software R 3.4.4.

\section{RESULTS}

\section{Uruguayan Yerba Mate Market}

Of the total amount of yerba mate exported by Brazil to all destinations, Uruguay in the last five years has participated with percentages which always remained above $85 \%$.

In 2013 considering all yerba mate exported by Brazil, 85.73\% had Uruguay as its final destination. In 2014 it was $88.44 \%, 2015$ it was $87.37 \%$, in 2016 the percentage reached $86.60 \%$ and $87.60 \%$ in 2017 (ALICEWEB, 2018). 
From the point of view of Uruguayan yerba mate imports, the main suppliers are Brazil, Argentina and Paraguay. In 2014, Uruguay imported 32,254 tons of Brazilian yerba mate, 330 tons from Argentina and 161 tons from Paraguay (DIRECCIÓN NACIONAL DE ADUANAS, 2018).

Between the years 2015 to 2018 the amount of yerba mate imported by Uruguay from Brazil underwent few changes with 32,939t in 2015, 32,401t in 2016, 30,952t in 2017 and 22,285t in 2018 (DIRECCIÓN NACIONAL DE ADUANAS, 2018). Constancy shows that it is a solid market.

\section{Evaluation of cycles and price behavior}

Unlike the analysis made by Cardoso et al. (2013) who plotted the prices on a graph and could perceive the variation of the cycles visually, for the present study it was decided to apply the Chow test to demonstrate when the structural breaks occurred (Table 1).

Tabela 1 - Quebras de tendência na série histórica dos preços pagos para erva-mate exportada para o Uruguai no período de janeiro de 1997 a abril de 2018.

Table 1 - Trend breaks in the historic series of prices paid for yerba mate exported to Uruguay from January 1997 to April 2018.

\begin{tabular}{lll}
\hline Break period & F value & Geometric rate of change by period $(\%)$ \\
\hline January 2003 & $265.7514^{*}$ & -1.42 \\
May 2004 & $6.3734^{*}$ & 0.083 \\
September 2012 & $559.5375^{*}$ & 0.95 \\
February 2014 & $1,284.187^{*}$ & 3.26 \\
January 2017 & $261.6314^{*}$ & -1.32 \\
Last period & - & 0.13 \\
\hline
\end{tabular}

* Significant coefficient from the Chow test, at a 95\% significance level.

The price of Brazilian yerba mate in the Uruguayan market in the time period studied showed 3 cycles (Figure 1). Only the end of the 1st cycle is identified, the 2 nd complete cycle and the beginning of the 3 rd cycle. For a better understanding of the results presented, the cycles were also divided into 6 periods.

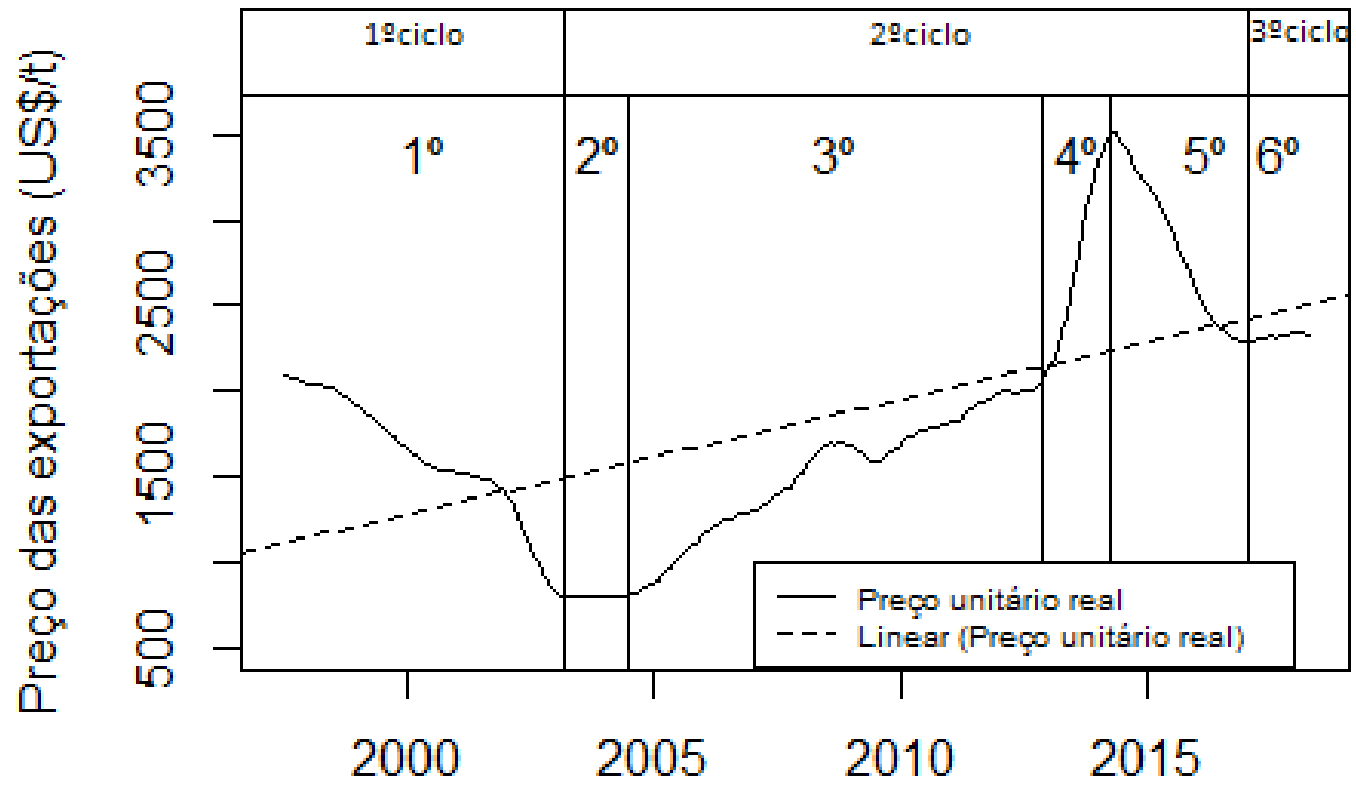

Ano

Figura 1 - Variação do preço unitário real dessazonalizado de Erva-mate exportada para o Uruguai no período de janeiro de 1997 a abril de 2018.

Figure 1 - Variation of the seasonally adjusted real unit price of Erva-mate exported to Uruguay from January 1997 to April 2018. 
The yerba mate market does not have regular historical cycles, showing a systematic decline from the beginning of the series until mid-January 2003 (1st period). From that moment on, there is a certain stability that lasts until May 2004 (2nd period).

From June 2004 until September 2012, the prices of yerba mate exported to Uruguay begin a recovery moment (3rd period). However, from October 2012 there is a great increase in prices that lasts until February 2014 (4th period), falling again exponentially from March 2014 until January 2017 (5th period). The last period observed seems to show a price trend for a possible recovery in the coming months, which would demonstrate the beginning of a new cycle, however, further studies must be carried out to prove the hypothesis.

On average the periods have a duration of 42 months, with the first period appearing with 73 months, the second period showing the shortest with only 16 months, the third with 100 months, the fourth period with 17 months, the fifth period 35 months. Finally, it is not possible to affirm that the sixth period is concluded, and prices should recover in the coming months.

\section{Seasonal variation pattern}

It is possible to observe a great oscillation in the seasonal variation pattern found for the prices of yerba mate exported to Uruguay, and as recommended by Soares et al (2015), price instability makes it difficult to define strategies for companies in the segment ( Figure 2).

The total amplitude of the seasonal variation pattern (difference between the highest and lowest value) was 28.79, a relatively smaller amplitude when compared other exported products, such as cellulose sold to China (SOARES et al, 2015) and the United States (CARDOSO et al, 2013) and plywood to the United States (DREYER, 2017). The highest index occurred in December 2013 (112.94), in the fourth period and the lowest occurred in October 2012 (84.14), in the first period.

Although the third period presented the greatest amplitude (4.23), it was the fourth period that registered the highest variation coefficient $(5.66 \%)$.

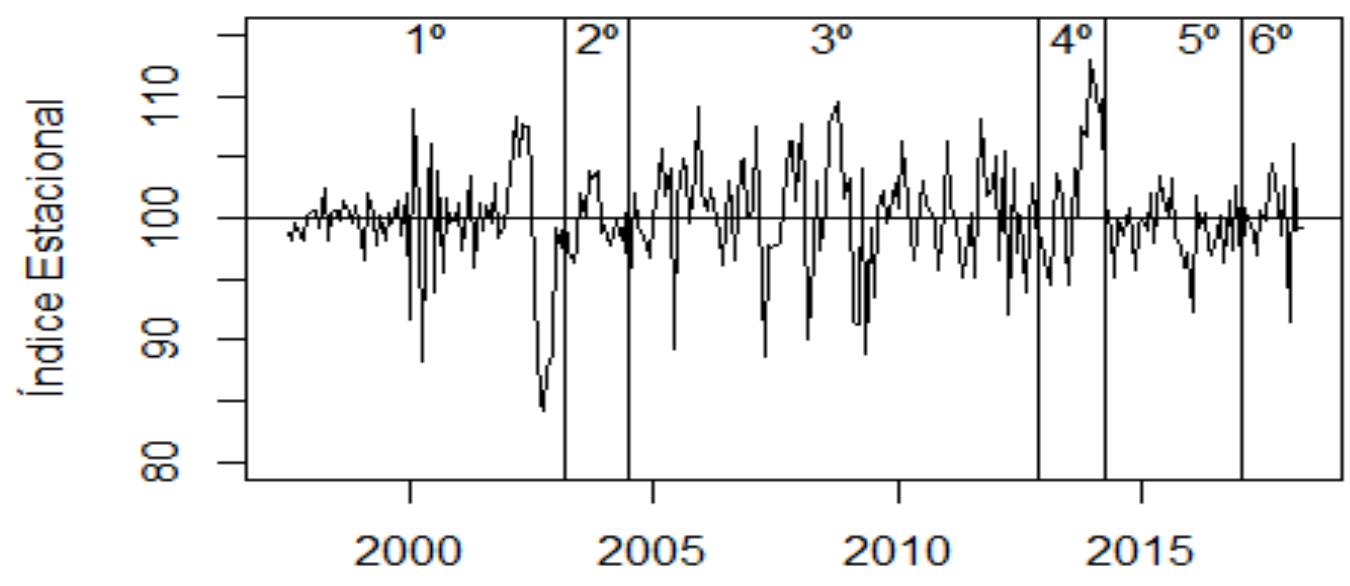

Ano

Figura 2 - Índice Estacional do preço da erva-mate exportada para o Uruguai.

Figure 2 - Seasonal index of the price of yerba mate exported to Uruguay.

The range of variation in prices around the average is quite irregular. This difference in amplitude and variation at the annual and period levels varies according to the conditions of supply and demand over the period studied, however it is possible to observe that for $90 \%$ of the period studied, the index was between 91.6 and 107.5.

\section{Seasonal variation pattern}

Through the Seasonal Indices (IS) it is possible to observe that every month presented a behavior very close to the average, with an amplitude of 2, with the lowest value occurring in May (98.7), which can be explained by coinciding with the period in which yerba mate is harvest, thus causing an increase in the supply of the product 
on the market and consequently pressure to reduction in prices. The highest seasonal index occurred in October (101.5), being this the best month for the commercialization of yerba mate with Uruguay (Figure 3).
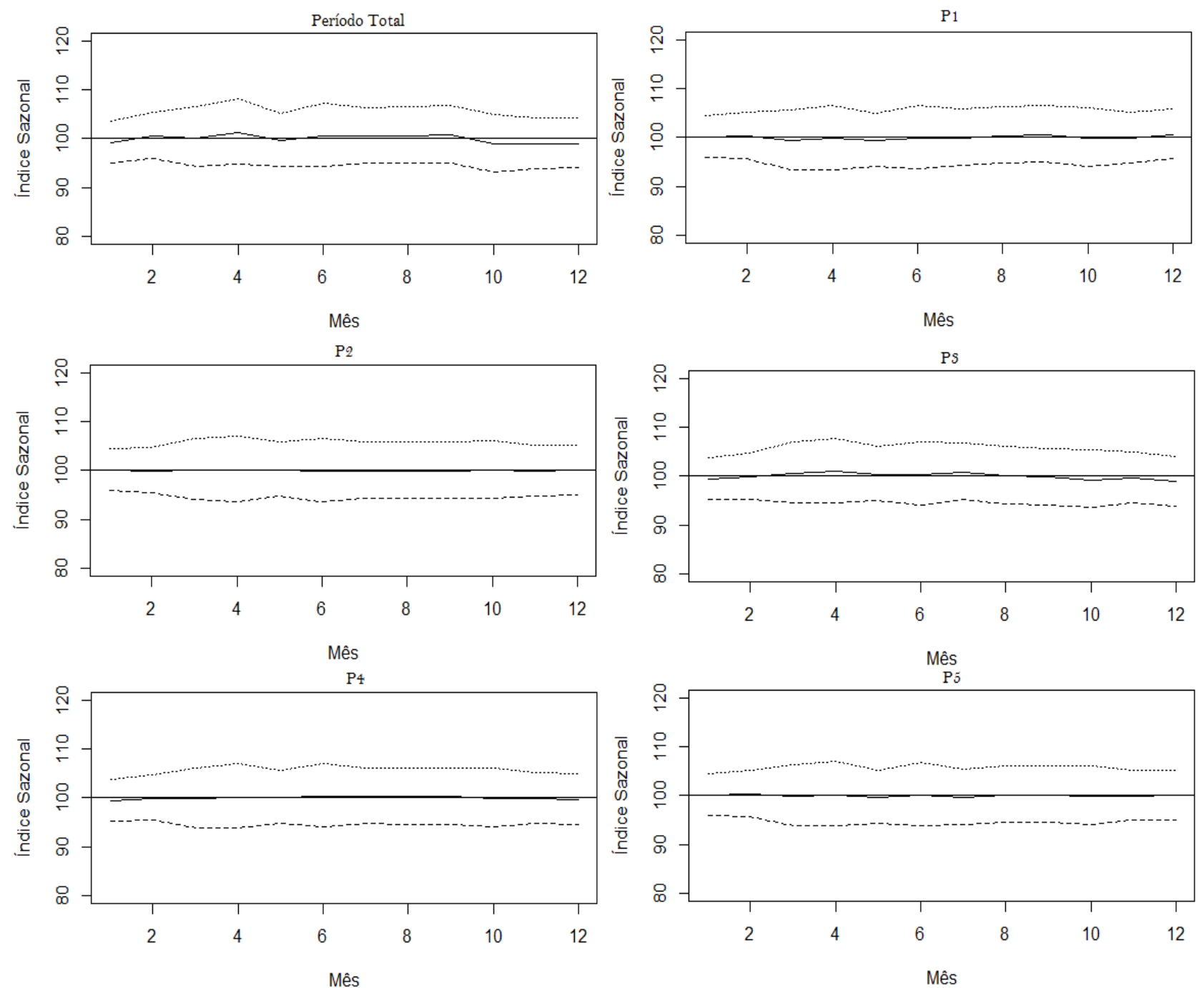

Figura 3 - Variação sazonal do preço da erva-mate exportada para o Uruguai nos períodos de análise.

Figure 3 - Seasonal variation of the yerba mate price exported to Uruguay during the analysis periods.

ANOVA results show a positive and high Spearman ordinal correlation coefficient between the different periods analyzed, showing that prices throughout the year, for all periods, show practically the same trend. (Table 2).

Tabela 2 - Análise da variância dos valores dos índices estacionais relativos aos preços recebidos pela erva mate exportada para o Uruguai (1997 - 2018)

Table 2 - Analysis of the variance of the values of the seasonal indices relative to the prices received for the exyerba mate exported to the Uruguay (1997 - 2018)

\begin{tabular}{c|c|c|l|c}
\hline Origin of variations & Sum of squares & Degrees of freedom & Square average & F \\
\hline $\begin{array}{c}\text { Months } \\
\text { (Seasonality) }\end{array}$ & 119502.053 & 11 & 10863.82297 & 0.925740852 \\
\cline { 1 - 3 } Residue & 1196793.08 & 119 & 10057.08474 & \\
Total & 1316295.14 & 130 & \multicolumn{2}{|c}{} \\
\cline { 1 - 3 } & & &
\end{tabular}




\section{DISCUSSION}

What can be seen is that since the beginning of the series the real unit price of Yerba Mate has been falling and it starts a gradual recovery from the beginning of the $3 \mathrm{rd}$ period on . It is possible to notice a rapid yerba mate price increase in the middle of the third period, which is equivalent to the beginning of 2008, this fact can be explained as reflecting the acquisition by Coca - Cola, of the largest mate-based drink company in Brazil, Leão Junior in 2007, mainly regarding ready-to-drink tea products. When the acquisition took place, for 230 million reais, its main brand, Matte Leão, accounted for $45 \%$ of the sales of ready-to-drink tea in the country (BASILE, 2007).

The growth projections from this acquisition were not consummated, and real prices maintained a gradual increase, without reaching a stability level. This fact is related to the country's growth moment, the lack of specific public policies for the yerba mate sector, the lack of organizational strategies mainly regarding agribusiness, more specifically the culture of grains, since many rural producers converted the use of the soil in crops that provide more immediate returns, such as corn and soybeans.

In the 4th period, especially from October 2012, it is possible to note that the real prices of yerba mate showed a considerable growth, until the months of February 2014, when there was an abrupt drop in prices from the 5th period ( March 2015). The increase seen in the 4th period is the result of a decrease in the supply of yerba mate for industries, due to the fall in extractive production between the years 2011 and 2013, and the production from cultivation between 2011 and 2012, reflecting an effect of increase in real prices.

The steep fall in prices observed since the beginning of the 5th period (March 2015) can be explained as a reflection of the temporary embargo on Brazilian yerba mate in the Uruguayan market. This embargo is the result of a civil inquiry initiated by the Uruguayan Justice to investigate the presence of lead and cadmium above the standards allowed in the product, as reported by the media at the time.

The fact that there is no cyclical pattern with well-defined periodicity, prevents the formulation of strategies for the product. Even so, Soares et al., (2015) suggest that, in order to achieve a competitive advantage, organizations should invest in periods when prices fall, in order to reap the results at a time of high prices.

In the short term, the prices of Brazilian yerba mate in the Uruguayan market are constantly shifting between falling and increasing movements. However, in general, observing the whole series, there is a long-term trend of an increase in the real price of the product at an average rate of $0.33 \%$ per month.

The low amplitude of the seasonal indexes results in a smaller margin of options to increase revenue from the formulation of strategies for the commercialization of yerba mate in months with higher seasonal indexes.

The seasonality of prices for agricultural products is due to the lack of adjustment between supply and demand, that is, supply is concentrated in a few months while demand lasts throughout the year.

\section{CONCLUSIONS}

- There is no defined cycle pattern for Brazilian yerba mate exported to Uruguay, as well as the non-existence of seasonality, thus, it is concluded that these cannot be parameters for planning relating the supply and demand of yerba mate by rural producers.

- It is necessary to understand the dynamics of the price and its behavior in order to optimize the gains as well as to establish the best times of sale of the product.

- One of the strategies used when there is seasonality is the stocking of the product waiting for the best price, however, this strategy does not apply to yerba mate exported to Uruguay, due to lack of seasonality.

- Although a price growth trend has been observed, it is not possible to say that the trend will remain positive, since there are several factors that influence the formation of the product's price.

- Although the seasonality analysis is important for the strategic management of the Brazilian herbal organization, it is noteworthy that the use of this tool alone does not allow the establishment of the best strategy for the commercialization of the Brazilian product in the Uruguayan market.

- The price of Brazilian yerba mate in the Uruguayan market was on the rise until the beginning of 2015, when the country's justice system launched an investigation to ascertain the presence of cadmium and lead at levels above that allowed in Brazilian yerba mate. Although nothing has been proven, the product has devalued against its importer.

- At the end of the study period, there is a slight tendency for prices to recover, however, only new studies will be able to prove whether the price of Brazilian yerba mate in the Uruguayan market will again reach levels similar to those registered before the judicial embargo. 


\section{ACKNOWLEDGMENT}

The authors would like to thank the Center for the Improvement of Higher Education Personnel (CAPES) for the granting of postgraduate scholarship in Forest Engineering.

\section{REFERENCES}

ALICE-WEB. Sistema de Análise das Informações de Comércio Exterior via Internet. 2018. Disponível em: <http://aliceweb.mdic.gov.br>. Acesso em: 14 mai. 2018.

BASILE, J. A defesa da multinacional junto ao CADE está pronta. Valor Econômico, São Paulo, 22 mar. 2007.

CARDOSO, M. V.; SOARES, P. R. C.; SILVA, J. C. G. L.; TIMOFEICZYK JUNIOR, R. Estudo da sazonalidade do preço da celulose brasileira no mercado dos Estados Unidos em períodos cíclicos como apoio a estratégias empresariais. Scientia Forestalis, Piracicaba, v. 41, n. 97, p. 047-055, mar. 2013.

CASTRO, J. E. G.; SOUSA NETO, J. M. Análise de técnicas de previsão de demanda com enfoque no planejamento da gestão de suprimentos. Revista Científica da Faculdade Darcy Ribeiro, Brasília, n. 04, jul/dez 2013.

CHECHI, L. A.; SCHULTZ, G. A produção de erva-mate: um estudo da dinâmica produtiva nos estados do sul do Brasil. Enciclopédia Biosfera, Goiânia, v.13, n.23, 2016.

CHOW, G. C.; Tests of Equality Between Sets of Coefficients in Two Linear Regressions. Econometrica, v. 28, n. 3, p. 591-605, 1960.

DALLABRIDA, V. R. Território E Desenvolvimento Sustentável: Indicação Geográfica Da Erva-Mate De Ervais Nativos No Brasil. Informe Gepec, Toledo, v. 16, nº 1, p. 42-59, 2012.

DIRECCIÓN NACIONAL DE ADUANAS. Estadísticas de Comercio Exterior. 2018. Disponível em: <https://www.aduanas.gub.uy/>. Acesso em: 26 mai. 2019.

DREYER, T. C.; SOUZA M. C.; PINTO, F. M.; SILVA, M. T. S.; OlIVEIRA, G. S., SOARES, P. R. C. Comportamento sazonal da exportação brasileira de compensado para os Estados Unidos entre 2004 a 2015. Revista Espacios, Caracas, v. 38, n. 37, p. 2-11, abril. 2017.

DUTRA, F. L. G.; HOFFMANN-RIBANI, R.; RIBANI, M. Determinação de compostos genólicos por cromatografia líquida de alta eficiência isocrática durante estacionamento da erva-mate. Química Nova, São Paulo, v.33, n.1, 2010.

ELIAS, G. A.; SANTOS, R. Produtos Florestais Não Madeireiros e Valor Potencial de Exploração Sustentável da Floresta Atlântica no Sul de Santa Cataria. Ciência Florestal, Santa Maria, v.26, n.1, p.249-262, jan.-mar., 2016.

HANSEN, B. E. The new econometrics of structural change: Dating breaks in U.S. labor productivity. The Journal of Economic Perspectives, Chhattisgarh, India, 15(4), p. 117-128. 2001.

HOFFMANN, R. Estatística para Economistas. São Paulo: Thomson, 2006. 432p.

MAISHAROU, A.; LARWANOU, M. Market potential of non-wood forest products in the Sahelian countries. International Forestry Review, Jakarta, Indonesia, v.17(S3), 2015.

OLIVEIRA, S. V.; WANQUIL, P. D. Dinâmica de produção e comercialização da erva-mate no Rio Grande do Sul, Brasil. Ciência Rural, Santa Maria, v. 45, n. 4, p. 750-756, abr. 2015.

ROCHA JUNIOR, W. F.; RINALDI, R. N.; ROCHA, V. L. B. F. Identificação de fatores competitivos no desenvolvimento do produto erva-mate. Revista Produção On-line, Florianópolis, v. 4, n. 3, 2004.

SANTANA A. C; SANTOS, M. A. S.; OLIVEIRA, C. M. Comportamento histórico da produção e comercio de madeira do estado do Pará nos mercados local e internacional. Amazônia: Ciência e Desenvolvimento, Belém, v. 6, n. 11, jul./dez. 2010.

SANTANA, L. F.; SOZINHO, T. M.; SILVA, J. C. G. L. FREGA, J. R.; ALMEIDA, L. B.; VALERIUS, J. Analysis of Seasonal Behavior, cycle occurrences and price trends of Brazil nut Products Exported from Brazil. Journal of Agricultural Science, Ontario, v. 10, n.5, 2018.

SOARES, P. R. C.; CARDOSO, M. V.; SCHIRIGATTI, E. L.; ALMEIDA, A. N.; GARZEL, J. C. L. S.; TIMOFEICZYK, R. T. Comportamento sazonal da exportação brasileira de celulose para a china entre 1997 e 2012. Floresta, Curitiba, v. 45, n. 2, p. 251-260, 2015. 
WOLF, R.; PEREIRA, M. W. G. Análise dos efeitos dos fluxos de comércio da erva-mate entre estados brasileiros e o Mercosul, entre 2002 e 2012. Ensaios FEE, Porto Alegre, v. 37, n. 3, p. 673-690, dez. 2016. 